\title{
Plant community development on petroleum drill sites in northwestern Wyoming
}

\author{
P.W. SMITH, E.J. DEPUIT, AND B.Z. RICHARDSON
}

\begin{abstract}
Plant community and soll development were investigated on oil/gas drilling sites occupying both sagebrush and coniferous forest vegetation types in northwestern Wyoming. Sites ranged from 3 to 33 years in age since abandonment. Some sites were seeded at abandonment, while others revegetated naturally. Vegetation and soils were sampled and compared on disturbed and adjacent undisturbed sites. Both soils and vegetation were altered by drilling activities. Disturbed soils generally had higher bullk density and pH and lower organic matter content than undisturbed soils. All disturbed sites were vegetationally dissimilar to adjacent native sites. However, sagebrush disturbances were progreasing toward undisturbed conditions more rapidly than coniferous forest disturbances. Seeding accelerated vegetation development, although at different rates between sagebrush and coniferous forest disturbances. Seeding and establishment of introduced grass species on disturbed sites did not prevent natural recolonization of native species.
\end{abstract}

Key Words: oil/eas drilling, reclamation, succession, soil development

Oil and gas exploration and production can have major impacts on rangelands and forest lands in the western United States. Reclamation of drill sites and ancillary disturbances is not only essential for alleviating such impacts, but is required by law.

Studies have been conducted within various ecosystems to determine the time required for natural revegetation after disturbance. Estimates of recovery have ranged from as little as $\mathbf{4 0}$ years for sagebrush communities (Tisdale and Hironaka 1981) up to 200 to 300 years for climax spruce-fir forests (Ronco 1976). This and other research (Judd 1940, Antos and Shearer 1981, Brown et al. 1976) suggest that reclamation techniques are necessary to accelerate plant community succession on disturbed lands, if recovery within a reasonable time frame is desired.

Much research has been conducted to characterize plant succession on disturbed lands and to identify factors controlling this process (e.g., Skilbred 1979, Doerr et al. 1984, Sindelar 1978, Jaynes and Harper 1978). Unfortunately, lands impacted by oil and gas exploration have received little emphasis in such research. These lands differ from many other disturbances because of the small-sized, often scattered and environmentally disparate nature of individual drill sites, and the necessity of extensive access road systems.

This project was conducted to evaluate succession on abandoned petroleum drill sites as influenced by time and a range of physical and biological factors. Specific objectives were to: (1) Evaluate the influence of surrounding vegetation, (2) Determine the effects of seeding vs. natural revegetation, and (3) Evaluate the influence of disturbance-induced edaphic changes, on plant community development.

Authors are presently plant ecologist, Wyoming Dept. Environmental Quality, 122 W. 25th St., Cheyenne, Wyo. 82002; associate professor, Range Management Dept., Univ. Wyoming, Laramie 82071; and research forester (retired), Intermountain Forest and Range Experiment Station, Logan, Utah 84321.

This study was a cooperative project between the Wyoming Agricultural Experiment Station and the USDA-Forest Service Intermountain Forest and R ange Experiment Station (Coop. Agreement No. INT-81-018-CA). The interest and direct support of personnel of the Bridger-Teton National Forest are also gratefully acknowledged. Manuscript accepted 5 April 1988.

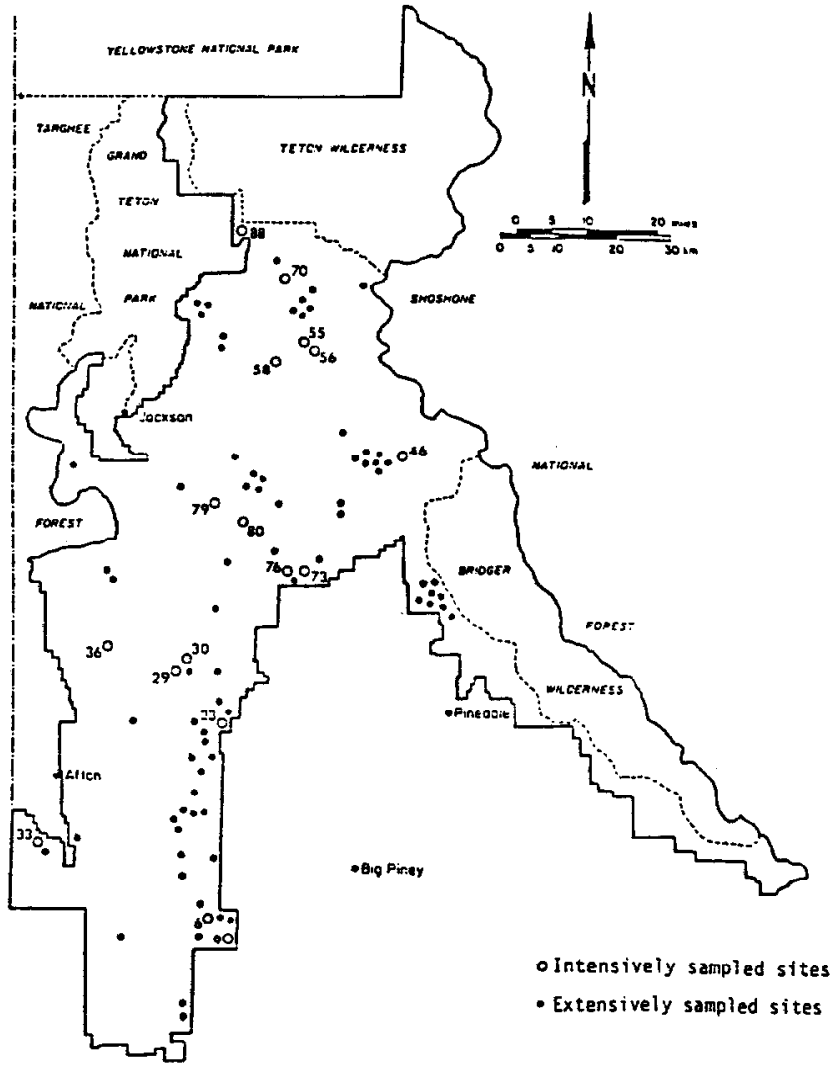

Fig. 1. Locations of intensively and extensively sampled drill sites within the Bridger-Teton National Forest, northwestem Wyoming. Identification numbers are adjacent to intensively sampled sites.

\section{Study Area}

All sampling was conducted on abandoned oil and gas drilling sites within the Bridger-Teton National Forest of northwestern Wyoming (Fig. 1). Plant communities within this Forest include grasslands, xerophytic shrublands, aspen and coniferous forests, and alpine plant communities (Beetle 1961, Bramble-Brodahl 1978, Youngblood and Mueggler 1981, Steele et al. 1983).

The Bridger-Teton National Forest occurs within a petroleum rich geologic formation known as the Overthrust Belt (Anschutes 1980). As a result, the Forest has been the focus of oil and gas exploratory operations for over 50 years. By 1981, at least 91 drill sites had been abandoned within the Forest.

\section{Methods}

\section{Study Design}

A field survey was conducted in 1981 to locate and qualitatively characterize most of the 91 abandoned drill sites. Results of this survey were presented by Waldvogel (1984).

It was impractical to intensively sample all sites for vegetation and soil characteristics. Therefore, a sub-array of 17 sites (Fig. 1) 
Table 1. Comparison of mean diaturbed and native area soil characteristics among aites withln the angebruah and coniferous vegetation types.

\begin{tabular}{|c|c|c|c|c|c|c|c|}
\hline \multirow[b]{2}{*}{ Soil attributel } & \multirow[b]{2}{*}{$\begin{array}{c}\text { Soil } \\
\text { depth }\end{array}$} & \multicolumn{3}{|c|}{ Sagebrush Sites } & \multicolumn{3}{|c|}{ Coniferous Sites } \\
\hline & & $\begin{array}{l}\text { Disturbed } \\
\text { areas }\end{array}$ & $\begin{array}{l}\text { Native } \\
\text { areas }\end{array}$ & $\begin{array}{c}\text { Significance } \\
\text { of } \\
\text { difference( } \alpha)\end{array}$ & $\begin{array}{l}\text { Disturbed } \\
\text { areas }\end{array}$ & $\begin{array}{l}\text { Native } \\
\text { areas }\end{array}$ & $\begin{array}{l}\text { Significance } \\
\text { of } \\
\text { difference }(\alpha)\end{array}$ \\
\hline $\begin{array}{l}\text { Bulk density } \\
\left(\mathrm{g} / \mathrm{cm}^{3}\right)\end{array}$ & $\begin{array}{l}1 \\
2 \\
3 \\
4 \\
5\end{array}$ & $\begin{array}{l}1.54 \\
1.54 \\
1.65 \\
1.74 \\
1.75\end{array}$ & $\begin{array}{l}1.21 \\
1.28 \\
1.35 \\
1.58 \\
1.53\end{array}$ & $\begin{array}{c}.01 \\
.10 \\
.10 \\
\text { none } \\
.01\end{array}$ & $\begin{array}{l}1.52 \\
1.72 \\
1.81 \\
1.79 \\
1.85\end{array}$ & $\begin{array}{l}1.23 \\
1.33 \\
1.40 \\
1.48 \\
1.66\end{array}$ & $\begin{array}{l}.01 \\
.01 \\
.01 \\
.05 \\
.01\end{array}$ \\
\hline ph & $\begin{array}{l}1 \\
2 \\
3 \\
4 \\
5\end{array}$ & $\begin{array}{l}6.9 \\
7.1 \\
7.3 \\
7.4 \\
7.4\end{array}$ & $\begin{array}{l}6.5 \\
6.6 \\
6.7 \\
6.6 \\
6.7\end{array}$ & $\begin{array}{l}.10 \\
.05 \\
.05 \\
.01 \\
.05\end{array}$ & $\begin{array}{l}7.0 \\
7.0 \\
6.9 \\
6.9 \\
7.0\end{array}$ & $\begin{array}{l}5.8 \\
5.6 \\
5.6 \\
5.7 \\
5.8\end{array}$ & $\begin{array}{l}.01 \\
.01 \\
.01 \\
.01 \\
.01\end{array}$ \\
\hline$\%$ Organic matter & $\begin{array}{l}1 \\
2 \\
3 \\
4 \\
5\end{array}$ & $\begin{array}{l}4.7 \\
4.6 \\
3.5 \\
2.8 \\
2.1\end{array}$ & $\begin{array}{l}9.2 \\
5.8 \\
3.9 \\
3.0 \\
2.5\end{array}$ & $\begin{array}{c}.05 \\
\text { none } \\
\text { none } \\
\text { none } \\
\text { none }\end{array}$ & $\begin{array}{l}3.5 \\
2.8 \\
3.0 \\
1.7 \\
1.8\end{array}$ & $\begin{array}{l}7.4 \\
6.3 \\
3.0 \\
2.1 \\
1.7\end{array}$ & $\begin{array}{c}.05 \\
.05 \\
\text { none } \\
\text { none } \\
\text { none }\end{array}$ \\
\hline $\begin{array}{l}\text { Available phosphorus } \\
\text { (m) }\end{array}$ & $\begin{array}{l}1 \\
2 \\
3 \\
4 \\
5\end{array}$ & $\begin{array}{l}27.0 \\
24.4 \\
23.0 \\
27.0 \\
19.2\end{array}$ & $\begin{array}{l}32.2 \\
29.4 \\
32.1 \\
27.8 \\
19.5\end{array}$ & $\begin{array}{l}\text { none } \\
\text { none } \\
\text { none } \\
\text { none } \\
\text { none }\end{array}$ & $\begin{array}{l}22.0 \\
16.9 \\
16.2 \\
16.2 \\
14.4\end{array}$ & $\begin{array}{l}20.1 \\
21.6 \\
28.8 \\
25.0 \\
23.1\end{array}$ & $\begin{array}{c}\text { none } \\
\text { none } \\
.10 \\
\text { none } \\
.10\end{array}$ \\
\hline $\begin{array}{l}\text { Exchangeable potassium } \\
(\mathrm{meq} / 100 \mathrm{~g})\end{array}$ & $\begin{array}{l}1 \\
2 \\
3 \\
4 \\
5\end{array}$ & $\begin{array}{l}.86 \\
.71 \\
.50 \\
.44 \\
.43\end{array}$ & $\begin{array}{r}1.07 \\
.96 \\
.83 \\
.72 \\
.57\end{array}$ & $\begin{array}{c}\text { none } \\
.10 \\
.10 \\
.10 \\
\text { none }\end{array}$ & $\begin{array}{l}.64 \\
.56 \\
.44 \\
.38 \\
.40\end{array}$ & $\begin{array}{l}.72 \\
.61 \\
.48 \\
.39 \\
.37\end{array}$ & $\begin{array}{l}\text { none } \\
\text { none } \\
\text { none } \\
\text { none } \\
\text { none }\end{array}$ \\
\hline $\begin{array}{l}\text { Effective rooting } \\
\text { depth }(\mathrm{cm})\end{array}$ & & 38 & 48 & .05 & 42 & 51 & .10 \\
\hline
\end{tabular}

'Data for CEC, EC, exchangeable cations and SAR are not presented due to lack of significant $(\alpha=, 01-.10)$ differences between disturbed and native areas.

$11=0-5 \mathrm{~cm} ; 2=6-10 \mathrm{~cm} ; 3=11-20 \mathrm{~cm} ; 4=21-30 \mathrm{~cm} ; 5=31-50 \mathrm{~cm}$.

was selected for intensive sampling which best represented the range of site variables to be investigated. These variables included.

\section{Nature of Surrounding Vegetation:} sagebrush/grassland vs. coniferous forest.

\section{Age of Site Since Abandonment}

\section{Presence vs. Absence of seeding.}

Nine of the 17 sites occupied sagebrush/grassland areas and ranged from 3 to 33 years in age since abandonment; 6 of these sites had been seeded. Eight sites were located within coniferous forest vegetation, also ranging from 3 to 33 years in age; 5 of the coniferous forest sites had been seeded. Waldvogel (1984) prorided a complete description of biophysical conditions for each 0 , the 17 sites.

A static approach (Austin 1977) was used to evaluate the successional status of abandoned drill sites. This method involves the derivation of trends from data collected at one point in time on a series of sites with varying ages or varying characteristics. Differences attributable to drilling disturbance were evaluated by comparing disturbed site data with concurrently collected undisturbed site data.

All 17 sites were sampled for soil attributes. Two sites selected initially were later judged inappropriate for vegetation sampling due to alteration of surrounding native vegetation. Consequently, vegetation sampling was confined to 15 sites.

\section{Sampling Procedures}

Vegetation and soil sampling were conducted once at each site during 1982. Results of tree overstory sampling on native coniferous forest sites were presented by Waldvogel (1984); this report will present results of herb, shrub, and tree seedling $(<140 \mathrm{~cm}$ in height) sampling only. Forty (40) was determined (Cook and Bonham 1977) to be an adequate sample size for all vegetation measurements. Therefore, 40 sample points were randomly located in each sampling zone (disturbed and native) at each drill site. The quadrat method of Daubenmire (1959) was used to estimate canopy cover at each sampling point. A $0.25-\mathrm{m}^{2}$ quadrat was used to estimate total vegetation cover, individual species cover, and ground cover. Vegetation descriptors generated from canopy cover included plant frequency, species composition, floristic richness and diversity (using the Shannon-Wiener Index [Shannon and Weaver 1973]).

Soils were characterized by sampling excavated pits within disturbed and native soils at each site. Soil depths sampled were 0-5, $6-10,11-20,21-30$, and $31-50 \mathrm{~cm}$. Effective rooting depth was visually identified at each pit. Each soil sample was analyzed for texture, organic matter content (Walkley-Black), pH (saturated paste), cation exchange capacity (CEC), electrical conductivity (EC, saturated paste), sodium adsorption ratio (SAR), calcium (Ca), magnesium (Mg), sodium $(\mathrm{Na})$, potassium $(\mathrm{K})$, phosphorus (P) and bulk density. All soil tests were conducted using procedures described by Black (1965), with the exception of organic matter (Greweling and Peech 1965).

\section{Data Analysis}

Plant and soil data were compared between disturbed and undisturbed areas, both at individual drill sites and among groups of sites wi: h similar characteristics (i.e., age, surrounding vegetation and/or seeding treatment). Results of soils analysis were averaged across disturbed and native sites within each vegetation type, and analyzed at varying levels of probability $(\alpha=0.01$ to 0.10$)$ using a paired $T$-test to identify any differences between disturbed and 


\begin{tabular}{|c|c|c|c|c|c|c|c|c|c|c|c|c|c|}
\hline & \multirow[t]{2}{*}{$\begin{array}{c}\text { Site } \\
\text { I.D. } \\
\text { number }\end{array}$} & \multirow{2}{*}{$\begin{array}{c}\text { Years } \\
\text { Since } \\
\text { abandon- } \\
\text { ment }\end{array}$} & \multirow{2}{*}{$\begin{array}{l}\text { Seeded } \\
\text { (S)/Non- } \\
\text { Seeded } \\
\text { (NS) }\end{array}$} & \multicolumn{2}{|c|}{$\begin{array}{c}\text { Total } \\
\text { vegetation }\end{array}$} & \multicolumn{2}{|c|}{$\begin{array}{c}\text { Perennial grasses } \\
\text { and grasslikes } \\
\end{array}$} & \multicolumn{2}{|c|}{ Perennial forbs } & \multicolumn{2}{|c|}{ Annual forbs } & \multicolumn{2}{|c|}{$\begin{array}{l}\text { Shrubs and } \\
\text { tree seedlings }\end{array}$} \\
\hline & & & & Dist. & Nat. & Dist. & Nat. & Dist. & Nat. & Dist. & Nat. & Dist. & Nat. \\
\hline \multirow[t]{2}{*}{$\begin{array}{l}\text { A. Sagebrush } \\
\text { Sites }\end{array}$} & $\begin{array}{l}58 \\
30 \\
29 \\
46 \\
73 \\
76 \\
88 \\
33\end{array}$ & $\begin{array}{r}3 \\
3 \\
12 \\
17 \\
18 \\
19 \\
24 \\
33\end{array}$ & $\begin{array}{c}\text { S } \\
\text { S } \\
\text { S } \\
\text { S } \\
\text { S } \\
\text { NS } \\
\text { NS } \\
\text { NS }\end{array}$ & $\begin{array}{l}18.2^{\mathrm{b}} \\
43.2^{\mathrm{b}} \\
34.8^{\mathrm{b}} \\
55.1^{\mathrm{b}} \\
29.4^{\mathrm{b}} \\
23.1^{\mathrm{b}} \\
48.4^{\mathrm{b}} \\
20.5^{\mathrm{b}} \\
\end{array}$ & $\begin{array}{l}49.0^{\circ} \\
64.4^{\circ} \\
63.1^{\circ} \\
66.0^{\circ} \\
47.8^{\circ} \\
50.5^{\circ} \\
61.8^{\circ} \\
66.0^{\circ} \\
\end{array}$ & $\begin{array}{r}15.2^{a} \\
35.6^{\natural} \\
30.2^{\natural} \\
15.3^{\mathrm{b}} \\
3.7^{\mathrm{b}} \\
5.0^{\mathrm{b}} \\
34.8^{\mathrm{a}} \\
5.6^{\mathrm{b}} \\
\end{array}$ & $\begin{array}{r}13.2^{\mathrm{a}} \\
20.2^{\mathrm{b}} \\
23.4^{\mathrm{b}} \\
23.7^{\mathrm{a}} \\
9.9^{\mathrm{a}} \\
19.8^{\mathrm{a}} \\
20.4^{\mathrm{b}} \\
14.8^{\mathrm{a}} \\
\end{array}$ & $\begin{array}{r}1.2^{\mathrm{b}} \\
3.6^{\mathrm{b}} \\
3.9^{\mathrm{b}} \\
32.8^{\mathrm{a}} \\
4.6^{\mathrm{b}} \\
16.3^{\mathrm{a}} \\
6.2^{\mathrm{b}} \\
7.7^{\mathrm{b}} \\
\end{array}$ & $\begin{array}{c}27.4^{\mathrm{a}} \\
27.3^{\mathrm{a}} \\
32.1^{\mathrm{a}} \\
32.4^{\mathrm{a}} \\
7.2^{\mathrm{a}} \\
9.1^{\mathrm{b}} \\
15.4^{\mathrm{a}} \\
31.3^{\mathrm{a}} \\
\end{array}$ & $\begin{array}{c}.5^{\mathrm{b}} \\
4.1 \\
1.9^{\mathrm{a}} \\
1.3^{\mathrm{a}} \\
1.0^{\mathrm{b}} \\
1.5^{\mathrm{a}} \\
0 \\
.5^{\mathrm{b}} \\
\end{array}$ & $\begin{array}{c}2.4^{\mathrm{a}} \\
0 \\
.3^{\mathrm{b}} \\
.1^{\mathrm{b}} \\
2.6^{\mathrm{a}} \\
1.5^{\mathrm{a}} \\
.6 \\
4.8^{\mathrm{a}} \\
\end{array}$ & $\begin{array}{r}.2^{b} \\
.1^{b} \\
0 \\
6.9^{b} \\
16.7^{b} \\
.7^{b} \\
6.5^{b} \\
9.1^{b} \\
\end{array}$ & $\begin{array}{r}8.5^{\mathrm{a}} \\
27.9^{\mathrm{a}} \\
21.4^{2} \\
15.9^{\mathrm{a}} \\
28.4^{\mathrm{a}} \\
20.7^{\mathrm{a}} \\
41.8^{\mathrm{a}} \\
23.0^{\mathrm{a}} \\
\end{array}$ \\
\hline & Mean & & & 34.1 & 58.6 & 18.2 & 18.2 & 9.5 & 22.8 & 1.4 & 1.5 & 5.0 & 23.4 \\
\hline \multirow[t]{2}{*}{$\begin{array}{l}\text { B. Coniferous } \\
\text { Sites }\end{array}$} & $\begin{array}{r}9 \\
36 \\
6 \\
80 \\
23 \\
56 \\
55\end{array}$ & $\begin{array}{r}3 \\
4 \\
9 \\
12 \\
21 \\
22 \\
28\end{array}$ & $\begin{array}{r}\text { S } \\
\mathbf{S} \\
\mathbf{S} \\
\mathbf{S} \\
\mathbf{S} \\
\mathrm{NS} \\
\mathrm{NS}\end{array}$ & $\begin{array}{l}19.0^{\mathrm{a}} \\
43.4^{\mathrm{a}} \\
15.0^{\mathrm{b}} \\
30.4^{\mathrm{b}} \\
36.0^{\mathrm{a}} \\
31.6^{\mathrm{b}} \\
46.5^{\mathrm{a}}\end{array}$ & $\begin{array}{l}25.7^{\natural} \\
44.5^{\mathrm{a}} \\
26.3^{\mathrm{a}} \\
51.7^{\mathrm{a}} \\
23.1^{\mathrm{b}} \\
81.1^{\mathrm{a}} \\
50.1^{\mathrm{a}}\end{array}$ & $\begin{array}{c}16.5^{\star} \\
37.4^{\star} \\
11.8^{\star} \\
15.8^{\star} \\
13.2^{\circ} \\
8.2^{\star} \\
11.4^{\star}\end{array}$ & $\begin{array}{c}3.1^{\mathrm{b}} \\
4.0^{\mathrm{b}} \\
3.8^{\mathrm{b}} \\
5.3^{\mathrm{b}} \\
0 \\
.1^{\mathrm{b}} \\
.3^{\mathrm{b}}\end{array}$ & $\begin{array}{r}.5^{\mathrm{b}} \\
2.2^{\mathrm{b}} \\
2.5^{\mathrm{b}} \\
4.4^{\mathrm{b}} \\
18.4^{\mathrm{a}} \\
11.8^{\mathrm{b}} \\
18.5^{\mathrm{a}}\end{array}$ & $\begin{array}{r}13.6^{\mathrm{a}} \\
28.8^{\mathrm{a}} \\
9.8^{\mathrm{a}} \\
33.5^{\mathrm{a}} \\
9.9^{\mathrm{b}} \\
22.8^{\mathrm{a}} \\
19.8^{\mathrm{a}}\end{array}$ & $\begin{array}{c}2.1^{a} \\
3.0^{a} \\
1.3^{n} \\
6.8^{a} \\
.1 \\
.4 \\
.3\end{array}$ & $\begin{array}{c}.2^{b} \\
.2^{b} \\
<.1^{b} \\
2.9^{b} \\
0 \\
0 \\
0\end{array}$ & $\begin{array}{c}.1^{b} \\
.3^{b} \\
0 \\
0 \\
3.4^{b} \\
1.4^{b} \\
2.5^{b}\end{array}$ & $\begin{array}{r}7.0^{\mathrm{a}} \\
13.2^{\mathrm{a}} \\
8.6 \\
5.2^{2} \\
16.1^{\mathrm{a}} \\
40.1^{\mathrm{a}} \\
28.5^{\mathrm{a}}\end{array}$ \\
\hline & Mean & & & 31.7 & 43.2 & 16.3 & 2.4 & 8.3 & 20.0 & 2.0 & .5 & 1.1 & 17.0 \\
\hline
\end{tabular}

IIndependently estimated; i.e. not sumed parameters.

${ }_{2}$ Values between disturbed-native site pairs followed by the same letter are not significantly different at $\alpha=.05$ (t-test).

native soils. A 2 -sample independent $T$-test was utilized to detect significant $(\alpha=0.05)$ differences in vegetation attributes between disturbed and native areas at each drill site. A similarity index designed by Spatz (Mueller-Dombois and Ellenburg 1974) was used to evaluate vegetation similarity for each pair of disturbed and native sites.

Simple and multiple linear regression was used to detect any relationships between edaphic or vegetation attributes and time. Ratios of disturbed to native site data (i.e., disturbed $\div$ native data at each site for each attribute) were used in most regressions because of the wide disparity in absolute data values among sites.

\section{Results}

\section{Soils}

Data indicated that exploratory drilling altered several physical and chemical soil properties (Table 1). Effective rooting depth was shallower in disturbed than in native soils within both vegetation types. Bulk densities were significantly higher in disturbed than in native soils at all depths within the coniferous vegetation type, and at most depths within the sagebrush type. It might be expected that differences in bulk density between disturbed and native sites would lessen over time. However, regression analyses indicated no such trend.

Soil $\mathrm{pH}$ was higher on disturbed soils within both vegetation types at all depths. The degree of difference varied among soil depths for sagebrush sites. A wider disparity in $\mathrm{pH}$ existed between disturbed and native soils within the coniferous type, and differences were always highly significant $(\alpha=0.01)$. Regression analysis did not indicate disturbed soil pH to become more similar to that of native soils over time.

Near-surface soil organic matter content was greater on native than on disturbed areas in both the sagebrush (at 0-5 cm depth) and the coniferous (at $0-5$ and 6-10 cm depths) vegetation types. These differences in organic matter did not diminish with time in the coniferous type. However, regression analysis of sagebrush site data did suggest a decline in organic matter differences between disturbed and native soils over time, although the significance of this trend was low $(\alpha=0.20)$.

Several soil attributes were either minimally or variably changed as a result of drilling disturbance. CEC, EC, SAR, and exchangeable cations were not altered by disturbance. No differences were detected in available $P$ between disturbed and native soils in the sagebrush type. Concentrations of $P$ in disturbed and native coniferous type soils were statistically different only at the 11-20 and $31-50 \mathrm{~cm}$ depths, where $P$ was greater in native soils. Within the sagebrush type, mean concentrations of $K$ were higher in native than in disturbed soils at all depths. However, no significant differences in $\mathrm{K}$ concentrations were detected at any soil depth within the coniferous type.

\section{Vegetation}

Total vegetation cover was significantly greater on native than on disturbed areas at nearly every drill site sampled (Table 2). No consistent pattern of increasing similarity in total cover between disturbed and native areas was apparent over time.

Perennial grass and grasslike species were usually dominant on seeded disturbed sites, and differences in cover between disturbed and native areas were generally significant. Grass cover on seeded sagebrush and coniferous disturbances was initially greater than that on native areas. However, regression analysis (Fig 2A) indicated that such differences declined over time, suggesting an eventual equilibration of grass cover between seeded disturbances and surrounding areas. On older, non-seeded sites, grass cover was consistently higher on disturbed than on native areas in the coniferous type, but relationships were inconsistent in the sagebrush type.

Perennial forb cover was generally lower on disturbed than on native areas. This relationship was strongest on more recently abandoned, seeded sites in both vegetation types. Linear regression analysis (Fig 2B) indicated that forb cover on disturbed areas increased relative to that on native areas over time. Analysis of seeded sites suggested a more rapid rate of forb increase for coniferous than for sagebrush disturbances. Regression analysis of all sites (seeded and non-seeded) did not yield a significant correlation in the sagebrush type, but did result in a positive correlation in the coniferous type. It is noteworthy that the rate of forb increase in the latter analysis was slower than when seeded sites only were analyzed. This suggests that seeding enhanced the rate of forb establishment on coniferous disturbances. Benefits of seeded grasses in 


\section{A. Perennial Grasses and Grasslikes}
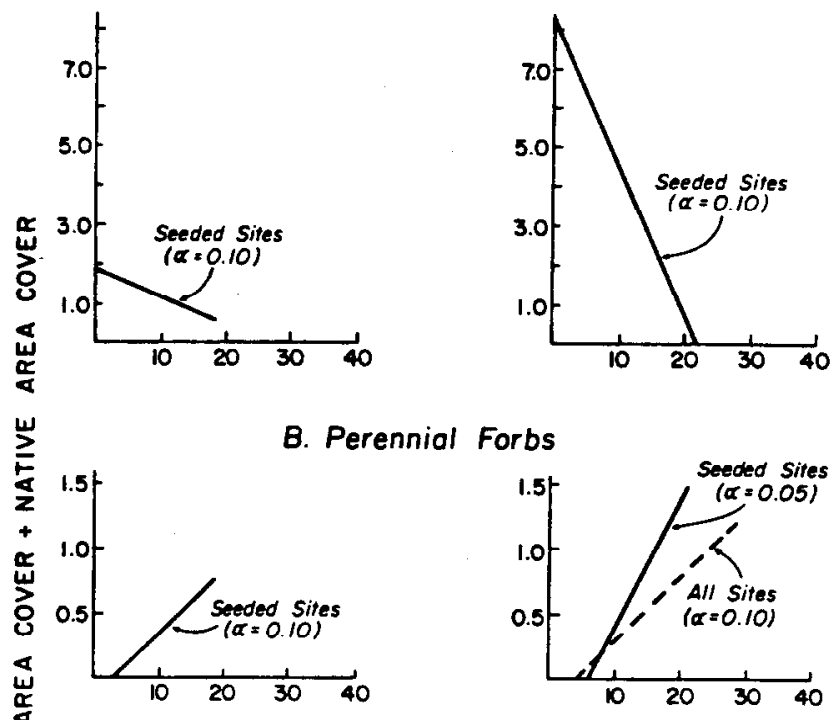

茴

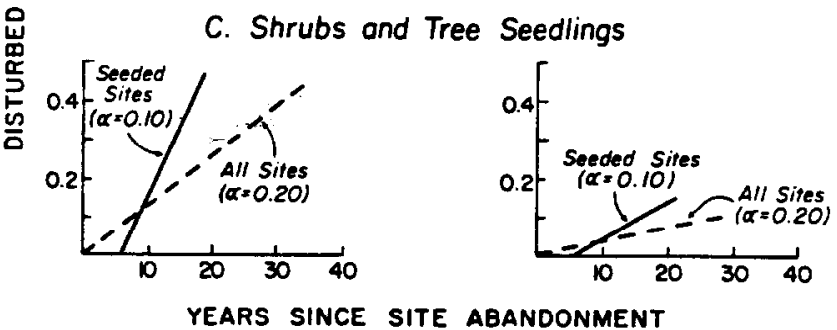

Fig. 2. Ratios of disturbed $\div$ native area plant class cover values over time, as derived from linear regression analyses of seeded and all sites.

site modification in this case may have outweighed effects of increased competition stress to forbs, resulting in enhanced forb establishment.
Shrub and tree seedling cover was always significantly lower on disturbed than on native areas. Shrubs and tree seedlings were either absent or very limited in cover on recently abandoned sites (i.e., $<12$ years in age) in both vegetation types. Tree seedlings were observed only on the 3 oldest coniferous forest disturbances. Despite their slow establishment, regression analysis (Fig. 2C) did indicate a trend of increasing shrub/tree seedling cover on disturbed relative to native areas over time. The rate of increase was far more rapid for sagebrush than for coniferous disturbances. In both vegetation types, regression analysis of seeded sites only indicated that shrub cover increased at a greater rate than when all sites (seeded plus non-seeded) were grouped and analyzed. As with forbs, shrub establishment was apparently favored by the seeding of disturbances.

Species richness and Shannon-Wiener diversity index $(\mathrm{H})$ relationships between disturbed and native areas varied for sagebrush and coniferous forest sites (Table 3 ). In the sagebrush type, both richness and $H^{\prime}$ values of disturbed and native areas generally converged over time among both seeded and non-seeded sagebrush sites.

Different patterns of richness and H' over time were apparent on coniferous sites. Seeded disturbances initially declined in richness and $\mathbf{H}^{\prime}$ relative to adjacent native areas. However, this trend eventually reversed; on seeded and non-seeded sites older than 12 years both richness and $\mathrm{H}^{\prime}$ on disturbed areas exceeded values on native areas.

A characteristic of most sites sampled was the relatively low number of plant species common to both disturbed and adjacent native communities (Table 3). This and the disproportionality of cover contributed by common species were reflected in low disturbed:native area similarity indices among sites (Table 3), ranging from 0.6 to $10.7 \%$.

Within the sagebrush type, disturbances tended to become more similar to surrounding native plant communities over time. Linear regression analyses of similarity indices vs. site age for both seeded and all (seeded and non-seeded) sites yielded weakly positive correlations $(\alpha=0.20)$. The rate of increase in similarity was more rapid for seeded sites, suggesting that seeding accelerated progression of sagebrush disturbances toward native conditions.

Similarity indices were generally lower in the coniferous than in the sagebrush vegetation type (Table 3). Furthermore, regression analysis of seeded coniferous sites resulted in a weakly negative

Table 3. Shannon-Wiener diveraity indices (H), floriatic richneas, number of common species and Spatz similarity indices (Iep) for disturbed and mative areas at each drill site.

\begin{tabular}{|c|c|c|c|c|c|c|c|c|}
\hline \multirow[b]{2}{*}{ Site I.D. \# } & \multirow{2}{*}{$\begin{array}{c}\text { Years since } \\
\text { abandonment }\end{array}$} & \multirow{2}{*}{$\begin{array}{c}\text { Seeded (S) or } \\
\text { Non-sceded (NS) }\end{array}$} & \multicolumn{2}{|c|}{$\mathbf{H}^{\prime}$} & \multicolumn{2}{|c|}{ Richness } & \multirow{2}{*}{$\begin{array}{l}\text { No. common } \\
\text { species' }\end{array}$} & \multirow[b]{2}{*}{ Isp? } \\
\hline & & & Disturbed & Native & Disturbed & Native & & \\
\hline $\begin{array}{l}\text { A. Sagebru } \\
\mathbf{5 8} \\
30 \\
29 \\
46 \\
73 \\
76 \\
88 \\
33\end{array}$ & $\begin{array}{r}3 \\
3 \\
12 \\
17 \\
18 \\
19 \\
24 \\
33\end{array}$ & $\begin{array}{r}\mathbf{S} \\
\mathbf{S} \\
\mathbf{S} \\
\mathbf{S} \\
\mathbf{S} \\
\mathbf{N S} \\
\mathbf{N S} \\
\mathbf{N S}\end{array}$ & $\begin{array}{l}0.84 \\
0.95 \\
0.96 \\
1.18 \\
0.82 \\
0.74 \\
0.77 \\
1.30\end{array}$ & $\begin{array}{l}1.44 \\
0.94 \\
1.20 \\
1.30 \\
0.85 \\
1.18 \\
0.93 \\
1.40\end{array}$ & $\begin{array}{l}33 \\
21 \\
24 \\
48 \\
28 \\
17 \\
20 \\
44\end{array}$ & $\begin{array}{l}62 \\
26 \\
54 \\
43 \\
30 \\
45 \\
33 \\
57\end{array}$ & $\begin{array}{r}13 \\
11 \\
14 \\
22 \\
14 \\
10 \\
9 \\
27\end{array}$ & $\begin{array}{r}1.7 \\
3.5 \\
1.6 \\
9.1 \\
10.7 \\
4.2 \\
3.9 \\
9.9\end{array}$ \\
\hline $\begin{array}{l}\text { B. Conifero } \\
9 \\
36 \\
6 \\
80 \\
23 \\
56 \\
55\end{array}$ & $\begin{array}{r}3 \\
4 \\
9 \\
12 \\
21 \\
22 \\
28\end{array}$ & $\begin{array}{r}\mathbf{S} \\
\mathbf{S} \\
\mathbf{S} \\
\mathbf{S} \\
\mathbf{S} \\
\mathbf{N S} \\
\mathbf{N S}\end{array}$ & $\begin{array}{l}1.08 \\
0.78 \\
0.60 \\
0.89 \\
1.08 \\
1.04 \\
0.99\end{array}$ & $\begin{array}{l}1.25 \\
1.00 \\
1.26 \\
1.62 \\
0.61 \\
0.61 \\
0.51\end{array}$ & $\begin{array}{l}35 \\
31 \\
21 \\
25 \\
31 \\
36 \\
41\end{array}$ & $\begin{array}{l}34 \\
49 \\
37 \\
80 \\
11 \\
17 \\
18\end{array}$ & $\begin{array}{r}12 \\
15 \\
7 \\
13 \\
3 \\
6 \\
8\end{array}$ & $\begin{array}{l}3.2 \\
2.4 \\
0.7 \\
1.7 \\
0.6 \\
0.8 \\
1.9\end{array}$ \\
\hline
\end{tabular}

ISpecies jointly occupying disturbed and native sites.

2Between disturbed and native plant communities. 
correlation ( $\alpha=0.20$ ) between index values and time. This suggests that the type of seeding practiced retarded the progression of disturbances toward native forest conditions.

\section{Discussion}

Although cover of plant classes became more similar between disturbed and native areas over time, plant species composition remained very different between disturbed and native communities over the 33-year time span represented by sites studied. This suggests that more time may be necessary for floristic (i.e., plant species) than for plant class recovery on disturbances sampled.

Vegetation data also indicated a slower rate and different pattern of recovery toward native conditions on coniferous forest disturbances than on sagebrush disturbances. In actuality, the rate of recovery of coniferous disturbances was probably slower than data indicated because the tree overstory of native sites was not represented in site comparisons. These differences between vegetation types may be attributable to several factors. As reviewed by Grime (1979) and others, in grass- or shrubland succession many species and life forms may be common to both early seral and climax stages. The higher and temporally increasing similarity of disturbed and native sites in the sagebrush vegetation type may reflect this relationship. Conversely, forest succession may be characterized by a more complete turnover in species and/or life form composition. This relationship may have partially contributed to the slower apparent recovery rates on coniferous disturbances.

Drilling activities in forested areas create openings in the tree canopy, thereby eliminating the shaded environment necessary for re-establishment of shade tolerant, climax species. Shade tolerant understory and tree species common to undisturbed forest communities were rarely encountered on disturbances. Instead, disturbances were colonized by shade intolerant species. Lodgepole pine (Pinus contorta), a shade intolerant mid-seral species (Ronco 1976), was the primary tree species establishing on older disturbances. The time required for establishment and growth of this species delayed availability of shaded habitats conducive to late-seral species. This may be a major factor contributing to slower rates of recovery for coniferous forest disturbances.

Sagebrush disturbances generally became more similar to native sites over time in terms of diversity. In contrast, diversity of coniferous forest disturbances initially declined relative to that of native areas but ultimately increased to exceed that of native areas. An eventual expression of higher diversity on mid-seral disturbances is not unexpected in view of the fact that mature coniferous forests often support only a small number of shade tolerant understory species (Antos and Shearer 1981).

Direct consequences of seeding on plant community development were not easily identifiable because only the more recently abandoned sites $(<21$ years) were seeded. Furthermore, the specific methods and rates of seeding applied varied among sites, as did species composition of seed mixes. However, all reclaimed sites were sown primarily with vigorous, competitive perennial grasses not native to the area, as well as introduced legume species on certain sites. Exclusive use of such introduced species has sometimes been reported to inhibit the reestablishment of native species (Laycock 1980, Schuman et al. 1982, Sindelar 1978). However, while seeded disturbances were dominated by introduced grasses, non-seeded native shrubs and forbs were also present. The younger, seeded sites generally possessed as many (or more) species in common with native communities as did older, non-seeded sites. Therefore, an extensive cover of seeded perennial grasses did not completely prevent native species establishment.

Similarity index data suggested that seeding introduced species accelerated successional progression toward native conditions on sagebrush disturbances. Site modification benefits from established introduced species may have enhanced the establishment of native species. However, absolute similarity of disturbed to native sagebrush plant communities was still low on even the oldest seeded sites. It is possible that changes in seeding practices, such as sowing primarily native rather than introduced species, may further accelerate succession and thereby shorten recovery time.

In contrast to the sagebrush type, the seeding of introduced grasses on coniferous forest disturbances negatively influenced their similarity to native communities over time. However, seeding did accelerate the establishment of non-seeded shrub and forb species. These seemingly contradictory relationships may be explained by the fact that the shrubs and forbs naturally colonizing disturbances were predominantly shade intolerant species not found in adjacent forest communities.

Changes in revegetation strategies for coniferous forest disturbances may increase the rate of recovery toward predisturbance condition. For example, seeding or planting practices may strive to establish not only early seral grasses but also mid-seral shrubs and trees (Ronco 1976) to hasten development of an environment conducive to later seral, shade tolerant species.

Changes in soil characteristics may have been major factors affecting vegetation development on sampled disturbances. The number, magnitude and statistical significance of disturbed:native soil differences were usually higher for coniferous than for sagebrush sites. This suggests that forest soils were more highly modified by drilling disturbance than shrubland soils, which may be another reason for slower rates of vegetation recovery on forest disturbances.

The increased bulk density of disturbed soils was probably attributable to soil compaction from the heavy equipment used on sites before and after drilling operations. Increased bulk density on non-topsoiled sites may also have been caused by the removal of less dense upper soil horizons during site preparation. Overly compacted soils can detrimentally affect plant establishment through negative effects on water availability (Hill and Sumner 1967) and may also directly reduce root growth. Bulk densities of 1.6 to $1.8 \mathrm{~g} \mathrm{~cm}^{-1}$, which were exhibited by many of the disturbed soils sampled, havo been shown to reduce root penetration (Foil and Ralston 1967, Zimmerman and Kardos 1961), and may have been one cause of the shallower effective rooting depth noted in disturbed soils.

Soil pH was usually higher in disturbed than in native soils. Within the sagebrush type, however, drilling disturbance did not increase pH sufficiently to warrant a change in acid or alkaline classification. In contrast, $\mathrm{pH}$ was strongly altered on coniferous forest disturbances. Most native soils varied in $\mathrm{pH}$ from 5.2 to 6.6, which is a normal, strongly to slightly acid range for forest soils (Spurr and Barnes 1973). Soil pH was generally within the neutral to slightly alkaline range of 7.0 to 7.6 for coniferous disturbances. This decrease in acidity in disturbed soils may have encouraged establishment of species normally not found on native soils because of non-adaptation to acidic conditions.

Percent organic matter in the upper $5 \mathrm{~cm}$ of disturbed soils was generally lower than that in native soils in both vegetation types. Topsoil loss or modification resulting from drilling activities may have removed or diluted organic matter at this uppermost soil depth. Organic matter is of critical importance to the function of plant:soil systems, and such reductions of soil organic matter content by disturbance can be detrimental to successional and pedogenic recovery (Schafer and Nielsen 1978). A trend of increasing organic matter content over time was apparent in disturbed sagebrush soils. However, no such trend was evident for disturbed coniferous forest soils, suggesting that equilibration of soil organic matter content may take far longer in that vegetation type.

\section{Conclusions}

The findings of this research must, in a proper sense, be considered tentative in light of the non-replicated, survey nature of the study, and of course specifically apply to the sampled drill sites only. Despite these limitations, we can conclude that drilling disturbance altered a number of soil attributes of sites sampled, and 
that certain of these alterations persisted for considerable periods of time. None of the drill sites sampled supported plant communities which closely resembled those of adjacent native areas. However, trends in vegetation recovery over time were apparent, and were interactively influenced by the nature of surrounding vegetation and seeding.

These conclusions allow a number of relationships to be hypothesized for drill site reclamation in the study area. First, they suggest that amelioration of detrimental changes in soils may be necessary in reclamation programs. Second, they suggest that rates and patterns of recovery can be expected to vary for drilling disturbances in disparate environments. Lastly, results suggest that while a given type of reclamation practice (i.e., grass seeding) may prove beneficial to environmentally different drilling disturbances, the nature of benefits will vary.

The dynamic nature of vegetation and soils on disturbances was demonstrated on sites sampled, and must be considered in reclamation planning. This implies that immediate or rapid achievement of pre-disturbance conditions should not be expected on drill sites in northwestern Wyoming. Instead, acceptable trends toward desired conditions should be sought through revegetation practices properly based on ecological principles.

\section{Literature Cited}

Anschutz, P.F. 1980. The Overthrust Belt: will it double U.S. gas reserves? World Oil 190:111-116.

Antos, J.A., and R.C. Shearer. 1981. Successional development in Abies grandis (Dougl.) forests in Swan Valley, western Montana. Northwest Sci. 55:26-29:

Austin, M.P. 1977. Use of ordination and other multivariant descriptive methods to study succession. Vegetatio 35:165-175.

Beetle, A.A. 1961. Range survey in Teton County, Wyoming. Part I: Ecology of range resources. Wyoming Agr. Exp. Sta. Bull. 376, Laramie

Black, C.A. (ed.). 1965. Methods of soils analysis. Amer. Soc. Agron., Series No. 9, Madison, Wis.

Bramble-Brodahl, M.K. 1978. Classification of Artemisia vegetation in the Gros Ventre Area, Wyoming. M.S. Thesis, Univ. Idaho, Moscow.

Brown, R.W., R.S. Johnston, B.Z. Richardson, and E.E. Farmer. 1976. Rehabilitation of alpine disturbances: Beartooth Plateau, Mt. p. 58-73. In: Proc, High-Altitude Revegetation Workshop No. 2, Colorado State Univ., Fort Collins.

Cook, C.W., and C.D. Bonham. 1977. Techniques for vegetation measurements and analysis for a pre- and post-mining inventory. Range Science Dept., Science Series No. 28. Colorado State Univ., Fort Collins.

Daubenmire, R.F. 1959. A canopy-coverage method of vegetational analysis. Northwest Sci. 33:43-64.

Doerr, T.B., E.F. Redente, and F.B. Reeves. 1984. Effects of soil disturbance on plant succession and levels of mycorrhizal fungi in a sagebrushgrassland community. J. Range Manage. 37:135-139.
Foll, R.R., and C.W. Ralston. 1967. The establishment and growth of loblolly pine seedlings on compacted soils. Soil Sci. Soc. Amer. Proc. 31:565-568.

Greweling, T., and M. Peech. 1965. Chemical soil tests. Cornell Univ. Agr. Exp. Sta. Bull. 960 . Ithaca, NY.

Grime, J.P. 1979. Plant strategies and vegetation processes. John Wiley and Sons, New York, NY.

Hill, J.N.S., and M.E. Sumner. 1967. Effect of bulk density on moisture characteristics of soils. Soil Sci. 103:234-238.

Jaynes, A.J., and K.T. Harper. 1978. Patterns of natural revegetation in arid southeastern Utah. J. Range Manage. 31:407-411.

Judd, B.I. 1940. Natural succession of vegetation on abandoned farm lands in Teton County, Mt. Agron. J. 32:330-336.

Laycock, W.A. 1980. What is successful reclamation-a look at the concepts of adaptability, productivity, cover and diversity of seeded species. p. 1-17. In: Proc. NW Colo. Land Recl. Sem. II, Steamboat Springs, Colo.

Mueller-Dombois, D., and H. Ellenbert. 1974. Aims and methods of vegetation ecology. John Wiley and Sons, New York, NY.

Ronco, F. 1976. Regeneration of forest lands at high elevations in the central Rocky Mountains. p. 13-28. In: Proc., High Altitude Revegetation Workshop No. 2, Colorado State Univ., Fort Collins.

Schafer, W.M., and G.A. Nielaen. 1978. Soil development and plant succession on 1 to 50-year old strip mine spoils in southeastern Montana. p. 541-549. In: Ecology and Coal Resource Development (M.K. Wali ed.), Pergamon Press, New York, NY.

Schuman, G.E., F. Rauzi, and D.T. Booth. 1982. Production and composition of crested wheatgrass-native grass mixtures. Agron. J. 74:23-26.

Shannon, C.E., and W. Weaver. 1973. The mathematical theory of communication. Univ. of Illinois Press, Urbana.

Sindelar, B.W. 1978. Successional development of vegetation on surface mined land in Montana. p. 550-560. In: Ecology and Coal Resource Development, M.K. Wali (ed.). Pergamon Press, New York, NY.

Skilbred, C.L. 1979. Plant succession on five naturally revegetated stripmined deposits at Colstrip, Montana. M.S. Thesis, Montana State Univ., Bozeman.

Spurr, S.H., and B.V. Barnes. 1973. Forest ecology (2nd edition), Ronald Press, New York, NY.

Steele, R., S.V. Cooper, D.M. Ondov, and R.D. Pfister. 1983. Forest habitat types of eastern Idaho-western Wyoming. USDA Forest Serv. Res. Pap. INT-144.

Tisdale, E.W., and M. Hironaka. 1981. The sagebrush-grass region: a review of the ecological literature. Forest, Wildlife and Range Exp. Sta. Bull. 33. Univ, of Idaho, Moscow.

Waldrogel, C.P. 1984. Plant community development on abandoned oil and gas drilling sites in western Wyoming. Unpub. M.S. Thesis, Univ. of Wyoming, Laramie.

Youngblood, A.P., and W.F. Muezeler. 1981. Aspen community types on the Bridger-Teton National Forest in western wyoming. USDA For. Serv. Res. Pap. Int-272.

Zimmerman, R.P., and L.T. Kardos. 1961. Effect of bulk density on root growth. Soil Sci. 91:280-288. 